\title{
DETERMINAN TINGKAT HUTANG PADA PERUSAHAAN PUBLIK YANG BERTAHAN DALAM POSISI JAKARTA ISLAMIC INDEX SELAMA 2004-2014
}

\author{
Indah Hapsari \\ Sekolab Tinggi Ilmu Ekonomi Perbanas Surabaya \\ indah.hapsari@perbanas.ac.id \\ Dewi Murdiawati \\ Sekolah Tinggi Ilmu Ekonomi Perbanas Surabaya \\ dewi.murdiawati@perbanas.ac.id
}

\begin{abstract}
Persisting in Jakarta Islamic Index positions for more than ten years was not easy. Managing the proportion of debt at the same time making its attractive to investors was also not simple. This study aims to analyze the determinants of debt from the surviving companies in Jakarta Islamic Index positions during 2004-2014. Using multiple linear regression, the adjusted $R 2$ was $66,3 \%$ and the results stated that managerial ownerships, institutional ownerships, independent commissioners, and liquidity could influence and control the level of debt. Meanwhile, profitability, assets structure, and company size had no significant efffect to debt. These results indicated the importance of managerial ownerships, institutional ownerships, independent commissioners, and liquidity as the determinats of debt in accordance with sharia (Bapepam-LK No.IX.A.13).
\end{abstract}

Keywords : Determinants, Debt, Sharia

\begin{abstract}
Abstrak
Bertahan dalam posisi Jakarta Islamic Index selama lebih dari sepuluh tahun bukanlah hal yang mudah. Mengatur komposisi hutang sekaligus menjadi penyedia saham syariah unggulan yang diminati investor juga bukanlah hal yang mudah. Penelitian ini bertujuan untuk menganalisis determinan atau faktor-faktir yang memengarubi tingkat butang dar perusahaan yang bertahan dalam Jakarta Islamic Index selama 2004-2014. Berdasarkan analisis regresi linier berganda, nilai adjusted R2 sebesar 66,3\% dan hasil menunjukkan babwa kepemilikan manajerial, kepemilikan institusional, komisaris inependen, dan likuiditas mampu memengarubi tingkat hutang. Sementara itu, profitabilitas, struktur aset, dan ukuran perusahaan tidak memiliki pengaruh terhadap tingkat tingkat hutang. Hal ini menunjukkan pentingnya kepemilikan manajerial, kepemilikan institusional, komisaris inependen, dan faktor likuiditas sebagai pengontrol tingkat hutang yang sesuai kriteria syariah dalam ketentuan Bapepam-LK No.IX.A.13.
\end{abstract}

Kata Kunci : Determinan, Hutang, Syariah

Permalink/DOI: http://dx.doi.org/10.18326/infsl3.v10i1.135-160 


\section{Pendahuluan}

Jakarta Islamic Index merupakan indeks yang mendasari ukuran kinerja saham-saham syariah, yang aktif dengan likuiditas perdagangan saham yang baik di pasar reguler, dan direview setiap enam bulan dalam setahun, yakni Januari dan Juli, atau periode lain yang ditetapkan Bapepam-LK. Jakarta Islamic Index menyediakan tiga puluh posisi saham syariah unggulan, dimana perusahaan dengan efek syariah harus mampu berkinerja maksimal untuk mampu bertahan dalam posisi indeks tersebut.

Tingkat hutang bagi perusahaan yang listing di Bursa Efek Indonesia, terutama pula bagi perusahaan-perusahaan dengan saham yang teridentifikasi memenuhi prinsip syariah tersebut, tentu merupakan suatu hal yang penting. Mengacu pada ketentuan Dewan Syariah Nasional dan Peraturan Bapepam-LK No.IX.A.13 mengenai penerbitan efek syariah, salah satu pertimbangan utama adalah terkait tingkat hutang, dimana rasio keuangan yang memuat proporsi hutang berbanding ekuitas ini tidak diperkenankan melebihi $82 \%$, atau dengan kata lain proporsi tingkat hutang maksimal adalah 45\%:55\%.

Menjadi bagian dari penyedia efek yang memenuhi kriteria syariah sekaligus memiliki posisi dalam Jakarta Islamic Index bukanlah hal yang mudah. Hal ini terbukti dari keluar masuknya perusahaan-perusahaan dalam indeks tersebut, sesuai yang tercantum dalam beberapa pengumuman PT Bursa Efek Indonesia terkait perhitungan Jakarta Islamic Index, yang terbit dua kali dalam setahun. Perusahaan publik yang menduduki posisi dalam Jakarta Islamic Index selama 2004 hingga 2014, berdasarkan lampiran Pengumuman BEJ No. Peng-418/BEJ-DAG/U/12-2003 tanggal 30 Desember 2003, dan selanjutnya yang selalu direview setiap enam bulan sekali, hingga lampiran Pengumuman BEI No.:Peng-00837/ BEI.OPP/11-2014 tanggal 27 November 2014, memang menunjukkan suatu pola dimana mempertahankan posisi dalam indeks tersebut, dengan kurun waktu yang lama, bukanlah perkara yang mudah. Dalam hal ini, pengendalian tingkat hutang sekaligus menjadikan sahamnya menarik bagi investor adalah pertimbangan yang utama. Oleh sebab itu, penelitian ini bermaksud menganalisis faktor-faktor 
yang mampu memengaruhi tingkat hutang pada perusahaan yang senantiasa bertahan dalam Jakarta Islamic Index, khususnya pada periode 2004-2014.

Sesuai teori agensi, keputusan terkait tingkat hutang yang dilakukan manajemen perusahaan selaku agen tidak akan selamanya seperti yang diharapkan oleh pihak penyedia dana atau prinsipal. Oleh sebab itu, mekanisme tata kelola yang baik muncul untuk meminimalisir konflik agensi tersebut. Kepemilikan manajerial dapat berperan dalam menyelaraskan kepentingan antara prinsipal dan agen (Jensen dan Meckling, 1976), kepemilikan institusional dapat berperan dalam mengawasi perilaku oportunistik manajemen (Jensen, 1986), serta komisaris independen bertindak sebagai pengendali internal tertinggi perusahaan yang memonitor dan mengarahkan perusahaan sehingga kepentingan prinsipal dan agen menjadi sejalan (Fama dan Jensen, 1983).

Beberapa penelitian terdahulu menyatakan adanya pengaruh kepemilikan manajerial, kepemilikan institusional, dan komisaris independen terhadap tingkat hutang perusahaan (Abdoli, Lashkary, dan Dehghani, 2012; Bobkin dan Arko, 2012; Hussainey dan Aljifri, 2012; Kajananthan, 2012; Mousavi, Jari, dan Aliahmadi, 2012; Kurniawan dan Rahardjo, 2014). Meski demikian, Moeinaddin dan Karimianrad (2012) serta Shoroki, Addin, dan Jamalabadi (2013) menyatakan tidak ada pengaruh antara kepemilikan manajerial, kepemilikan institusional, maupun komisaris independen terhadap tingkat hutang.

Selanjutnya, sesuai teori pecking order, perusahaan pada dasarnya memiliki preferensi untuk memilih sumber pendanaannya. Dalam hal ini, Myers dan majluf (1984) mengemukakan bahwa perusahaan dapat mempertimbangkan sumber dana internal (laba ditahan) atau sumber dana eksternal (hutang atau penerbitan saham). Pilihan sumber dana ini mendorong manajemen untuk memiliki komposisi sumber pendanaan yang sesuai bagi perusahaan. Bagi perusahaan terutama yang berupaya untuk menjadikan sahamnya sesuai prinsip syariah, komposisi terkait tingkat hutang menjadi penting. Beberapa faktor yang mampu memengaruhi tingkat hutang dalam penelitian terdahulu antara lain profitabilitas, likuiditas, 
struktur aset, dan ukuran perusahaan (Margaretha dan Ramadhan, 2012; Sultera, Suhadak, dan Darminto, 2014; Widyarini dan Muid; 2014).

Margaretha dan Ramadhan (2012) menyatakan bahwa profitabilitas, likuiditas, dan ukuran perusahaan berpengaruh terhadap tingkat hutang. Sementara itu, Sultera, Suhadak, dan Darminto (2014) mengemukakan bahwa likuiditas dan struktur aset berpengaruh terhadap tingkat hutang sedangkan profitabilitas dan ukuran perusahaan tidak berpengaruh terhadap tingkat hutang. Terakhir, Widyarini dan Muid (2014) menyimpulkan bahwa profitabilitas, likuiditas, dan struktur aset berpengaruh terhadap tingkat hutang sedangkan ukuran perusahaan tidak berpengaruh terhadap tingkat hutang.

Berdasarkan uraian sebelumnya, penelitian ini akan menganalisis determinan atau faktor-faktor yang memengaruhi tingkat hutang pada perusahaan yang bertahan dalam posisi Jakarta Islamic Index selama periode 2004-2014. Berdasarkan pula pada adanya research gapyang ada, maka determinan tingkat hutang yang dimaksud dalam penelitian ini mencakup kepemilikan manajerial, kepemilikan institusional, komisaris independen, profitabilitas, likuiditas, struktur aset, dan ukuran perusahaan.

\section{Tinjauan Pustaka}

Teori Agensi merupakan teori yang lahir dari adanya pemisahan antara prinsipal (pemilik perusahaan) dan agen (manajemen perusahaan) yang cenderung memunculkan suatu konflik agensi akibat ketidakselarasan kepentingan antara pemilik dengan manajemen perusahaan (Jensen dan Meckling, 1976). Pada dasarnya, manajemen dapat berperilaku oportunistik yang menguntungkan pihaknya namun tidak selaras dengan harapan atau kepentingan pemilik. Hal ini menimbulkan masalah keagenan, dan untuk meminimalisir jurang perbedaan antara kepentingan pemilik dengan manajemen perusahaan, maka suatu tata kelola perusahaan pun ditekankan. 
Pihak manajemen yang sekaligus berperan sebagai pemilik perusahaan mengandung pemahaman bahwa manajemen akan berperilaku sebaik-baiknya demi kemakmuran atau kekayaannya. Dengan demikian, kepemilikan manajerial mengindikasikan adanya suatu kesamaan kepentingan yang mampu mempersempit jurang dalam konflik keagenan, karena pihak manajemen turut merasakan memiliki perusahaan tersebut. Dalam hal pengelolaan tingkat hutang, pihak manajemen yang bertindak juga sebagai pemilik cenderung menghindari risiko dari tingkat hutang yang besar, karena hal ini mampu memengaruhi kepentingannya sebagai pengelola maupun pemilik perusahaan. Selain itu, pihak manajemen, terutama bagi perusahaan penyedia efek syariah, juga akan berupaya untuk mengelola tingkat hutang, dimana komposisi hutang terhadap ekuitas diupayakan tidak akan menyimpang dari ketentuan BAPEPAM-LK. Bobkin dan Arko (2012) serta Kurniawan dan Rahardjo (2014) menyatakan adanya pengaruh kepemilikan manajerial terhadap tingkat hutang.

H1 : Kepemilikan manajerial berpengaruh terhadap tingkat hutang

Pemilik institusi memiliki insentif untuk mengawasi perusahaan (Jensen, 1986), sementara itu, komisaris independen merupakan pengendali internal tertinggi yang mengawasi dan mengarahkan perusahaan (Fama dan Jensen, 1983). Monitoring yang dilakukan keduanya merupakan upaya untuk mengendalikan perilaku oportunistik perusahaan sehingga turut meminimalisir konflik keagenan yang ada. Terkait hal pengelolaan tingkat hutang, pihak pemilik institusi cenderung menginginkan risiko yang rendah dari suatu tingkat hutang, sedangkan komisaris independen akan mengawasidanmengarahkan perusahaanuntuktidakmembahayakan perusahaan dengan risiko yang besar dari suatu tingkat hutang yang tinggi. Selain itu, terutama bagi perusahaan penyedia efek syariah, fungsi monitoring juga akan turut mengendalikan perusahaan dalam keputusan pengelolaan tingkat hutangnya, dimana komposisi hutang terhadap ekuitas diupayakan tidak menyimpang dari ketentuan BAPEPAM-LK. Abdoli, Lashkary, dan Dehghani (2012), Hussainey dan Aljifri (2012), Mousavi, Jari, dan Aliahmadi (2012), serta Kurniawan dan Rahardjo (2014) mengemukakan adanya pengaruh antara kepemilikan institusional terhadap tingkat hutang, sedangkan 
Abdoli, Lashkary, dan Dehghani (2012), Bobkin dan Arko (2012), serta Kajananthan (2012) menyimpulkan pengaruh antara komisaris independen terhadap tingkat hutang.

H2 : Kepemilikan institusional berpengaruh terhadap tingkat hutang H3 : Komisaris independen berpengaruh terhadap tingkat hutang

Teori pecking order mengakui adanya suatu urutan prioritas sumber dana, dimana perusahaan dapat memilih sumber dana internal dari laba ditahan, atau sumber dana eksternal berupa hutang atau penerbitan saham (Myers dan majluf, 1984). Adapun hirarki dalam pencarian sumber dana adalah sumber dana internal yaitu laba ditahan, dan apabila sumber dana internal tidak mencukupi, maka perusahaan akan mencari sumber dana eksternal baik melalui hutang maupun penerbitan saham. Meski tidak ada penjelasan detil terkait komposisi sumber pendanaan eksternal yang baik, namun perusahaan tetap ditekankan untuk tidak memiliki sumber pendanaan eksternal yang tinggi. Dalam hal saham yang memenuhi prinsip syariah, adapun rasio tingkat hutang yang diperkenankan tidak melebihi $82 \%$, atau dengan kata lain proporsi tingkat hutang maksimal adalah 45\%: 55\%.

Berdasarkan teori pecking order, salah satu urutan prioritas sumber dana adalah sumber dana internal yang berasal dari laba ditahan. Dalam hirarki pencarian sumber dana pun sumber dana internal ditekankan terlebih dahulu karena sifatnya yang murah, mudah, dan tidak berisiko layaknya hutang. Ketika perusahaan memiliki kemampuan untuk menghasilkan laba dengan baik, maka perusahaan dapat menggunakan sumber dana internal tersebut untuk membiayai aktivitas operasional dan investasinya, sehingga berkontribusi di dalam menekan proporsi tingkat hutang sekaligus memperkecil risiko yang muncul dari tingginya tingkat hutang. Terkendalinya komposisi tingkat hutang ini juga akan membantu perusahaan untuk menjadi penerbit efek yang sesuai prinsip syariah. Margaretha dan Ramadhan (2012), dan Widyarini dan Muid (2014) menyatakan bahwa profitabilitas memiliki pengaruh terhadap tingkat hutang.

H4 : Profitabilitas berpengaruh terhadap tingkat hutang 
Ketika kesulitan keuangan terjadi akibat tingginya tingkat hutang, maka likuiditas pun akan terganggu. Berdasarkan teori pecking order, perusahaan dengan tingkat likuiditas yang baik cenderung menekan tingkat hutangnya. Perusahaan dengan aset lancar yang memadai akan mampu membiayai kegiatan operasional dan investasinya serta memilih sumber pendanaan internal yang murah dan tidak beresiko layaknya hutang. Penekanan sumber pembiayaan dari hutang pun dapat terjadi dan memperkecil kemungkinan adanya tingkat hutang yang melebihi ketentuan saham syariah dalam BAPEPAM-LK. Margaretha dan Ramadhan (2012), Sultera, Suhadak, dan Darminto (2014), dan Widyarini dan Muid (2014) menyatakan bahwa likuiditas memiliki pengaruh terhadap tingkat hutang.

H5 : Likuiditas berpengaruh terhadap tingkat hutang

Dalam hirarki teori pecking order, ketika sumber dana internal tidak memadai untuk membiayai aktivitas perusahaan, maka perusahaan akan menggunakan sumber daya eksternal. Aset tetap yang besar memberi keyakinan bagi pihak manajemen untuk mulai mencari sumber pembiayaan eksternal. Aset tetap yang dimiliki perusahaan menjadi salah satu pertimbangan kreditur di dalam keputusan peminjaman hutang. Ketika perusahaan menghadapi suatu kesulitan keuangan, maka aset tetap dapat berfungsi sebagai jaminan di dalam pemenuhan kewajibannya. Aset tetap yang dimiliki perusahaan mampu memengaruhi perilaku manajemen untuk lebih agresif dan lebih percaya diri terkait keputusan hutang. Kecenderungan ini mengindikasikan bahwa struktur aset dapat memengaruhi komposisi tingkat hutang perusahaan. Sultera, Suhadak, dan Darminto (2014), serta Widyarini dan Muid (2014) menyatakan bahwa struktur aset memiliki pengaruh terhadap tingkat hutang.

H6 : Struktur Aset berpengaruh terhadap tingkat hutang

Ukuran perusahaan menggambarkan pula seberapa besar kebutuhan akan pembiayaan aktivitas keseluruhan perusahaan. Ketika aktivitas perusahaan kurang mampu dibiayai secara memadai dari sumber pendanaan internal perusahaan, maka alternatif sumber pembiayaan eksternal pun terbuka. Hal ini memacu timbulnya 
kenaikan komposisi pembiayaan eksternal, seperti hutang. Perusahaan dengan ukuran besar berpotensi menghasilkan arus kas yang memadai karena diversifikasi usahanya, dan membuka peluang yang mudah dalam mencari sumber dana melalui hutang. Kecenderungan ini mengindikasikan bahwa ukuran perusahaan dapat memengaruhi komposisi tingkat hutang perusahaan. Margaretha dan Ramadhan (2012) menyatakan bahwa ukuran perusahaan memiliki pengaruh terhadap tingkat hutang.

H7 : Ukuran perusahaan berpengaruh terhadap tingkat hutang

\section{Metode Penelitian}

Penelitian ini merupakan penelitian kuantitatif dengan pengujian hipotesis yang menganalisis determinan tingkat hutang. Adapun determinan tingkat hutang sebagai variabel independen yang dimaksud adalah kepemilikan manajerial, kepemilikan institusional, komisaris independen, profitabilitas, likuiditas, struktur aset, dan ukuran perusahaan. Sementara itu, variabel independen penelitian adalah tingkat hutang.

Populasi dalam penelitian ini adalah tiga puluh posisi perusahaan publik dalam Jakarta Islamic Index (JII), sedangkan sampel dalam penelitian ini adalah perusahaan publik yang selalu menduduki posisi dalam Jakarta Islamic Index selama 2004 hingga 2014, berdasarkan lampiran Pengumuman BEJ No. Peng-418/ BEJ-DAG/U/12-2003 tanggal 30 Desember 2003, dan selanjutnya yang selalu direview setiap enam bulan sekali, hingga lampiran Pengumuman BEI No.:Peng-00837/BEI.OPP/11-2014 tanggal 27 November 2014.

Adapun data sekunder penelitian yang diperoleh berupa data laporan keuangan 2004-2014 dari ICMD (Indonesian Capital Market Directory) dan situs resmi Bursa Efek Indonesia (www.idx.co.id), yang didomentasikan, diseleksi, dan kemudian untuk diolah lebih lanjut sesuai dengan maksud penelitian. Penelitian ini menggunakan pengujian dengan regresi linier berganda, yang menguji antara dua atau lebih variabel independen terhadap variabel dependen (Ghozali, 2013), dengan persamaan sebagai berikut: 


$$
\mathrm{DER}=\alpha+\beta_{1} \mathrm{KMj}+\beta_{2} \mathrm{KIns}+\beta_{3} \mathrm{KInd}+\mathrm{b}_{4} \mathrm{Pft}+\mathrm{b}_{5} \mathrm{Lkd}+\mathrm{b}_{6} \mathrm{SA}+\mathrm{b}_{7} \mathrm{UP}+\varepsilon
$$

Keterangan:

DER : Tingkat Hutang, diukur dengan debt to equity ratio

a : Konstanta

$\mathrm{KMj} \quad$ : Kepemilikan Manajerial, diukur dengan dummy variabel ( 1 = memiliki kepemilikan manajerial ; $0=$ tidak memiliki kepemilikan manajerial)

KIns : Kepemilikan Institusional, diukur dengan persentase kepemilikan institusional

Kind : Komisaris Independen, diukur dengan persentase komisaris independen dalam dewan komisaris

Pft : Profitabilitas, diukur dengan laba bersih dibagi total aset

Lkd : Likuiditas, diukur dengan aset lancar dibagi hutang lancar

SA : Struktur Aset, diukur dengan aset tetap dibagi total aset

UP : Ukuran perusahaan, diukur dengan Ln total aset

$\beta_{1-} b_{7} \quad$ : Koefisien regresi yang di estimasi

$\varepsilon \quad$ : error term

\section{Pembahasan}

Penelitian ini menguji determinan tingkat hutang pada perusahaan publik yang bertahan dalam posisi Jakarta Islamic Index selama 20042014. Jakarta Islamic Index memuat tiga puluh perusahaan publik yang sahamnya memenuhi kriteria atau prinsip syariah sesuai Dewan Syariah Nasional dan Peraturan Bapepam-LK No.IX.A.13 mengenai penerbitan efek syariah, sekaligus memiliki transaksi perdagangan saham yang aktif atau likuiditas perdagangannya baik. Sampel perusahaan yang masuk dalam Jakarta Islamic Index pada penelitian ini adalah sesuai dengan peraturan: 1) Lampiran Pengumuman PT Bursa Efek Jakarta No. Peng-418/BEJ-DAG/U/12-2003 tanggal 30 Desember 2003, untuk saham Jakarta Islamic Index (JII) pada periode Januari hingga Juni 2004. 2) Lampiran Pengumuman PT 
Bursa Efek Jakarta No. Peng-175/BEJ-DAG/U/06-2004 tanggal 25 Juni 2004 Desember 2003, untuk saham Jakarta Islamic Index (JII) pada periode Juli hingga Desember 2004. 3) Lampiran Pengumuman PT Bursa Efek Jakarta No. No. Peng-499/BEJ-DAG/U/12-2004 tanggal 28 Desember 2004, untuk saham Jakarta Islamic Index (JII) pada periode Januari hingga Juni 2005. 4) Lampiran Pengumuman PT Bursa Efek Jakarta Peng-171/BEJ-DAG/U/06-2005 tanggal 27 Juni 2005 untuk, saham Jakarta Islamic Index (JII) pada periode Juli hingga Desember 2005. 5) Lampiran Pengumuman PT Bursa Efek Jakarta No. Peng-468/BEJ-DAG/U/12-2005 tanggal 28 Desember 2005, untuk saham Jakarta Islamic Index (JII) pada periode Januari hingga Juni 2006. 6) Lampiran Pengumuman PT Bursa Efek Jakarta No. Peng-149/BEJ-DAG/U/06-2006 tanggal 26 Juni 2006, untuk saham Jakarta Islamic Index (JII) pada periode Juli hingga Desember 2006. 7) Lampiran Pengumuman PT Bursa Efek Jakarta No. Peng461/BEJ-DAG/U/12-2006 tanggal 27 Desember 2006, untuk saham Jakarta Islamic Index (JII) pada periode Januari hingga Juni 2007. 8) Lampiran Pengumuman PT Bursa Efek Jakarta No. Peng-192/ BEJ-DAG/U/06-2007 tanggal 29 Juni 2007, untuk saham Jakarta Islamic Index (JII) pada periode Juli hingga Desember 2007. 9) Lampiran Pengumuman PT Bursa Efek Indonesia No. Peng-032/ BEI-DAG/U/12-2007 tanggal 27 Desember 2007, untuk saham Jakarta Islamic Index (JII) pada periode Januari hingga Juni 2008. 10) Lampiran Pengumuman PT Bursa Efek Indonesia No. Peng133/BEI-PSH/U/06-2008 tanggal 6 Juni 2008, untuk saham Jakarta Islamic Index (JII) pada periode Juli hingga Desember 2008. 11) Lampiran Pengumuman PT Bursa Efek Indonesia No. Peng-494/ BEI-PSH/U/12-2008 tanggal 5 Desember 2008, untuk saham Jakarta Islamic Index (JII) pada periode Desember 2008 hingga Mei 2009. 12) Lampiran Pengumuman PT Bursa Efek Indonesia No. Peng00062/BEI-PSH/U/06-2009 tanggal 4 Juni 2009, untuk saham Jakarta Islamic Index (JII) pada periode Juni hingga November 2009. 13) Lampiran Pengumuman PT Bursa Efek Indonesia No. Peng-00412/ BEI-PSH/U/12-2009 tanggal 4 Desember 2009, untuk saham Jakarta Islamic Index (JII) pada periode Desember 2009 hingga Mei 2010. 14) Lampiran Pengumuman PT Bursa Efek Indonesia No. Peng00141/BEI-PSH/U/06-2010 tanggal 3 Juni 2010, untuk saham Jakarta 
Islamic Index (JII) pada periode Juni hingga November 2010. 15) Lampiran Pengumuman PT Bursa Efek Indonesia No. Peng-00598/ BEI-PSH/U/12-2010 tanggal 3 Desember 2010, untuk saham Jakarta Islamic Index (JII) pada periode Desember 2010 hingga Mei 2011. 16) Lampiran Pengumuman PT Bursa Efek Indonesia No. Peng00160/BEI-PSH/U/07-2011 tanggal 7 Juni 2011, untuk saham Jakarta Islamic Index (JII) pada periode Juni 2011 hingga November 2011. 17) Lampiran Pengumuman PT Bursa Efek Indonesia No. Peng00632/BEI-PSH/U/12-2011 tanggal 6 Desember 2011, untuk saham Jakarta Islamic Index (JII) pada periode Desember 2011 hingga Mei 2012. 18) Lampiran Pengumuman PT Bursa Efek Indonesia No. Peng-00147/BEI-PSH/U/05-2012 tanggal 30 Mei 2012, untuk saham Jakarta Islamic Index (JII) pada periode Juni hingga November 2012. 19) Lampiran Pengumuman PT Bursa Efek Indonesia No. Peng00631/BEI-PSH/U/12-2012 tanggal 30 November 2012, untuk saham Jakarta Islamic Index (JII) pada periode Desember 2012 hingga Mei 2013. 20) Lampiran Pengumuman PT Bursa Efek Indonesia No. Peng-00170/BEI-PSH/U/05-2013 tanggal 29 Mei 2013, untuk saham Jakarta Islamic Index (JII) pada periode Juni hingga November 2013. 21) Lampiran Pengumuman PT Bursa Efek Indonesia No. Peng-00673/BEI-PSH/U/11-2013 tanggal 28 /November 2013, untuk saham Jakarta Islamic Index (JII) pada periode Desember 2013 hingga Mei 2014. 22) Lampiran Pengumuman PT Bursa Efek Indonesia No. Peng-00235/BEI-OPP/U/05-2014 tanggal 28 Mei 2014, untuk saham Jakarta Islamic Index (JII) pada periode Juni 2014 hingga November 2014. 23) Lampiran Pengumuman PT Bursa Efek Indonesia No. Peng-00837/BEI-OPP/U/11-2014 tanggal 27 November 2014, untuk saham Jakarta Islamic Index (JII) pada periode Desember 2014 hingga Mei 2015

Berdasarkan Lampiran Pengumuman BEJ No. Peng-418/ BEJ-DAG/U/12-2003 tanggal 30 Desember 2003 sampai dengan Lampiran Pengumuman BEI No.:Peng-00837/BEI.OPP/11-2014 tanggal 27 November 2014, pada tiga puluh posisi yang ada dalam Jakarta Islamic Index dan senantiasa direview setiap enam bulan sekali tersebut, terdapat enam perusahaan publik yang mampu bertahan dalam kurun waktu 2004-2014,. Adapun enam perusahaan publik yang dimaksud adalah PT Indocement Tunggal Prakarsa, 
Tbk., PT Kalbe Farma, Tbk., PT Tambang Batu Bara Bukit Asam, Tbk., PT Telekomunikasi Indonesia, Tbk., PT United Tractors, Tbk., dan PT Unilever Indonesia, Tbk. Dengan demikian, jumlah sampel perusahaan per tahun adalah enam perusahaan, dan dengan periode penelitian sebelas tahun (selama kurun waktu 2004-2011), maka didapat sebanyak 66 sampel perusahaan yang diuji dalam penelitian ini selama periode penelitian 2004-2014.

\section{Tabel 1 Sampel Penelitian}

\begin{tabular}{clc}
\hline No & \multicolumn{1}{c}{ Nama Perusahaan } & Kode Emiten \\
\hline 1 & PT Indocement Tunggal Prakarsa, Tbk. & INTP \\
2 & PT Kalbe Farma, Tbk. & KLBF \\
3 & PT Tambang Batu Bara Bukit Asam, Tbk. & PTBA \\
4 & PT Telekomunikasi Indonesia, Tbk. & TLKM \\
5 & PT United Tractors, Tbk. & UNTR \\
6 & PT Unilever Indonesia, Tbk. & UNVR \\
\hline
\end{tabular}

\section{Sumber : Data yang diolab}

Selanjutnya, pada statistik deskriptif akan disajikan gambaran masing-masing variabel penelitian, yaitu tingkat hutang (DER) sebagai variabel dependen, dan kepemilikan manajerial (KMj), kepemilikan institusional (KIns), komisaris independen (Kind), profitabilitas (Pft), likuiditas (Lkd), struktur aset (SA), dan ukuran perusahaan (UP) sebagai variabel independen dari perusahaan sampel selama periode penelitian 2004 hingga 2014.

\begin{tabular}{cccccc}
\hline \multicolumn{7}{c}{ Tabel 2 } \\
Statistik Deskriptif \\
& $\mathrm{N}$ & Minimum & Maximum & Mean & $\begin{array}{c}\text { Std. } \\
\text { Deviation }\end{array}$ \\
KIns & 66 & .5100 & .8500 & .626986 & .1129417 \\
Kind & 66 & .0000 & .5714 & .297238 & .1610592 \\
Pft & 66 & .0119 & .4214 & .192495 & .1031769 \\
Lkd & 66 & .5416 & 6.9821 & 2.553595 & 1.7499942 \\
SA & 66 & .0553 & .8000 & .405005 & .2208793
\end{tabular}




\begin{tabular}{cccccc} 
DER & 66 & .1464 & 2.1053 & .780515 & .5096566 \\
UP & 66 & 28.5003 & 32.5790 & 30.325153 & 1.0762220 \\
Valid N & 66 & & & & \\
(listwise) & & & & & \\
\hline
\end{tabular}

Sumber : Data yang diolah, SPSS

Tabel 3

Frekuensi Kepemilikan Manajerial (KMj)

\begin{tabular}{cccccc}
\hline & & Frequency & Percent & $\begin{array}{c}\text { Valid } \\
\text { Percent }\end{array}$ & $\begin{array}{c}\text { Cumulative } \\
\text { Percent }\end{array}$ \\
\hline \multirow{4}{*}{ Valid } & 0 & 37 & 56.1 & 56.1 & 56.1 \\
& 1 & 29 & 43.9 & 43.9 & 100.0 \\
& Total & 66 & 100.0 & 100.0 & \\
\hline
\end{tabular}

Sumber : Data yang diolah, SPSS

Berdasarkan Tabel 2, nilai maksimum kepemilikan institusional adalah 85\% dan nilai minimum kepemilikan institusional adalah 51\%. Selanjutnya, proporsi komisaris independen terbesar sebanyak 57,14\% dan yang terkecil adalah 0\%. Profitabilitas dan likuiditas tertinggi sebesar 0,42 dan 6,98 sedangkan yang terkecil sebesar 0,01 dan 0,54. Adapun nilai maksimum struktur aset dan debt to equity ratio (DER-Tingkat hutang) adalah 0,8 dan 2,1 sementara nilai minimumnya adalah 0,06 dan 0,15. Ukuran perusahaan tertinggi sebesar 32,58 dan ukuran perusahaan terendah sebesar 28,5. Terakhir, pada sampel perusahaan berdasarkan tabel 3, terdapat $56,1 \%$ selama tahun penelitian yang tidak memiliki kepemilikan manajerial dan terdapat $43,9 \%$ selama kurun waktu penelitian 20042014 yang memiliki kepemilikan manajerial. Besarnya persentase kepemilikan manajerial berkisar antara 0,0000001 hingga 0,35 dimana sebagian besar persentase tersebut berada di bawah 1\%. 
Tabel 4

One-Sample Kolmogorov-Smirnov Test

\begin{tabular}{llr}
\hline & & Unstandardized Residual \\
\hline $\mathrm{N}$ & Mean & 66 \\
& Normal Parameters ${ }^{\mathrm{a}, \mathrm{b}}$ & .0000000 \\
& Std. & .27964390 \\
& Deviation & \\
Most Extreme & Absolute & .093 \\
Differences & Positive & .093 \\
& Negative & -.072 \\
Test Statistic & & .093 \\
Asymp. Sig. (2-tailed) & & $.200^{\mathrm{c}, \mathrm{d}}$ \\
\hline
\end{tabular}

Sumber: Data yang diolah, SPSS

\section{Tabel 5}

Model Summary ${ }^{b}$

\begin{tabular}{|c|c|c|c|c|c|}
\hline Model & $\mathrm{R}$ & $\begin{array}{c}\mathrm{R} \\
\text { Square }\end{array}$ & $\begin{array}{c}\text { Adjusted R } \\
\text { Square }\end{array}$ & $\begin{array}{l}\text { Std. Error } \\
\text { of the } \\
\text { Estimate }\end{array}$ & $\begin{array}{l}\text { Durbin- } \\
\text { Watson }\end{array}$ \\
\hline 1 & $.836^{\mathrm{a}}$ & .699 & .663 & .2960384 & 1.970 \\
\hline
\end{tabular}

Sumber: Data yang diolah, SPSS 
Tabel 6

Coefficients $^{\text {a }}$

\begin{tabular}{llcc}
\hline \multicolumn{1}{c}{ Model } & \multicolumn{2}{c}{ Collinearity Statistics } \\
& (Constant) & Tolerance & VIF \\
\hline \multicolumn{2}{c}{ KMj } & .379 & 2.637 \\
& KIns & .233 & 4.288 \\
& KInd & .139 & 7.175 \\
& Pft & .604 & 1.655 \\
& Lkd & .293 & 3.412 \\
& SA & .453 & 2.206 \\
\multicolumn{2}{c}{ a. Dependent Variable: DER } & .345 & 2.895 \\
\hline
\end{tabular}

Sumber: Data yang diolah, SPSS

Berdasarkan Tabel 4, residual data terdistribusi normal dimana nilai kolmogorov-smirnov sebesar 0,093 dengan tingkat signifikansi 0,200 di atas 0,05. Dengan demikian, model regresi sudah memenuhi asumsi normalitas. Berdasarkan nilai Durbin-Watson pada Tabel 5, tidak terjadi autokorelasi dimana nilai Durbin-Watson 1,970 adalah lebih besar dari batas atas (du) 1,880 dan kurang dari (4-du) 2,1196. Adapun nilai tolerance dari masing-masing variabel pada Tabel 6 berada di atas 0,1 dan nilai VIF berada di bawah 10, sehingga model regresi tidak mengindikasikan adanya multikolinieritas dan asumsi non multikolinieritas terpenuhi. Terakhir, tidak terjadi heteroskedastisitas berdasarkan Gambar 1 berikut ini, dimana titiktitik cenderung menyebar dan tidak membentuk suatu pola tertentu. 


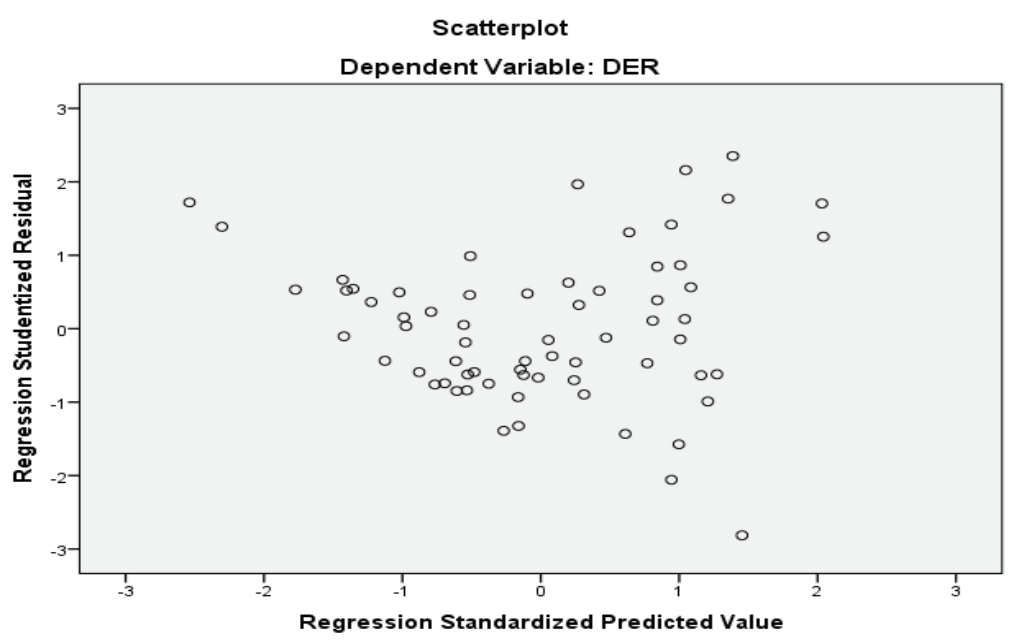

Gambar 1

Sumber : Data yang diolah, SPSS

Adapun regresi linear berganda antara kepemilikan manajerial, kepemilikan institusional, komisaris independen, profitabilitas, likuiditas, struktur aset, dan ukuran perusahaan terhadap tingkat hutang (DER) menghasilkan hasil sebagai berikut :

Tabel 7

Hasil Analisis Regresi

\begin{tabular}{lccc}
\hline \multicolumn{1}{c}{ Variabel } & Koefisien & Signifikansi & Hipotesis \\
\hline Konstanta & 0,404 & & \\
Kepemilikan Manajerial (KMj) & 0,268 & 0,028 & Diterima \\
Kepemilikan Institusional (KIns) & $-1,432$ & 0,038 & Diterima \\
Komisaris Independen (Kind) & $-2,673$ & 0,000 & Diterima \\
Profitabilitas (Pft) & 0,272 & 0,554 & Ditolak \\
Likuiditas (Lkd) & $-0,094$ & 0,019 & Diterima \\
Struktur Aset (SA) & 0,115 & 0,642 & Ditolak \\
Ukuran Perusahaan (UP) & 0,069 & 0,240 & Ditolak \\
Adj. R Square & 0,663 & & \\
F & 19,236 & & \\
Sig. F & 0,000 & & \\
\hline
\end{tabular}

Sumber: Data yang diolah, SPSS 
Model regresi linier berganda yang dihasilkan adalah :

$$
\begin{gathered}
\text { DER }=0,404+0,268 \mathrm{KMj}-1,432 \mathrm{KIns}-2,673 \mathrm{KInd}+0,272 \mathrm{Pft} \\
-0,094 \mathrm{Lkd}+0,115 \mathrm{SA}+0,069 \mathrm{UP}+\varepsilon
\end{gathered}
$$

Berdasarkan Tabel 7, konstanta sebesar 0,404 menyatakan bahwa jika tidak memperhitungkan variabel kepemilikan manajerial, kepemilikan institusional, komisaris independen, profitabilitas, likuiditas, struktur aset, dan ukuran perusahaan, maka kemungkinan tingkat hutang perusahaan sampel adalah sebesar 0,404. Selanjutnya, terdapat empat hipotesis yang diterima, dimana nilai signifikansi dari variabel kepemilikan manajerial, kepemilikan institusional, komisaris independen, dan likuiditas berada di bawah tingkat signifikasi ( $\alpha$ ) 5\%. Dengan demikian, dapat dikatakan bahwa kepemilikan manajerial berpengaruh terhadap tingkat hutang, kepemilikan institusional berpengaruh terhadap tingkat hutang, komisaris independen berpengaruh terhadap tingkat hutang, dan likuiditas berpengaruh terhadap tingkat hutang. Sementara itu, terdapat tiga hipotesis lainnya yang ditolak, dimana nilai signifikansi dari variabel profitabilitas, struktur aset, dan ukuran perusahaan berada di atas tingkat signifikasi ( $\alpha$ ) 5\%. Dengan demikian, dapat disebutkan bahwa profitabilitas tidak berpengaruh terhadap tingkat hutang, struktur aset tidak berpengaruh terhadap tingkat hutang, dan ukuran perusahaan tidak berpengaruh terhadap tingkat hutang.

Berdasarkan tabel 7, nilai F sebesar 19,236 dengan signifikansi sebesar 0,000 di bawah 0,05. Hal ini mencerminkan bahwa model dalam penelitian tergolong model yang fit. Selanjutnya, koefisien determinasi yang terlihat dari nilai adjusted $R$ square yaitu sebesar 0,663, atau dengan kata lain variabel kepemilikan manajerial, kepemilikan institusional, komisaris independen, profitabilitas, likuiditas, struktur aset, dan ukuran perusahaan mampu menjelaskan tingkat hutang (DER) pada perusahaan sampel selama kurun waktu 2004-2014 sebesesar 66,3\%, dan sisanya sebesar 33,7\% dipengaruhi oleh faktor lain yang tidak diteliti.

Berdasarkan hasil pengujian regresi dalam tabel 7 , kepemilikan manajerial memiliki pengaruh terhadap tingkat hutang pada perusahaan publik yang bertahan dalam posisi Jakarta 
Islamic Index selama kurun waktu penelitian 2004-2014. Hal ini terbukti dengan adanya nilai koefisien regresi variabel kepemilikan manajerial sebesar 0,268 dengan signifikasi sebesar 0,028 yang berada di bawah tingkat signifikasi $(\alpha)$ 5\%. Hasil penelitian ini berbeda dengan hasil penelitian Moeinaddin dan Karimianrad (2012) serta Shoroki, Addin, dan Jamalabadi (2013) yang menyatakan tidak adanya pengaruh antara kepemilikan manajerial terhadap tingkat hutang. Meski demikian, hasil penelitian ini sejalan dengan hasil penelitian Bobkin dan Arko (2012) serta Kurniawan dan Rahardjo (2014) yang menyatakan adanya pengaruh kepemilikan manajerial terhadap tingkat hutang.

Dalam sudut pandang agensi, kepemilikan manajerial dianggap mampu menyelaraskan kepentingan pemilik dan pengelola perusahaan. Meski tingkat hutang yang tinggi cenderung menimbulkan risiko bagi perusahaan sekaligus mengingatkan manajemen terkait ambang batas tingkat hutang dalam prinsip efek syariah, namun hasil penelitian mencerminkan bahwa perusahaan yang memiliki kepemilikan manajerial justru tertarik untuk memperoleh sumber pendanaan dari hutang dibanding perusahaan yang tidak memiliki kepemilikan manajerial. Hal ini menandakan pihak manajemen yang bertindak pula sebagai pemilik perusahaan ternyata memiliki suatu optimisme di dalam kemampuan melunasi pinjamannya, dengan menyediakan sebuah kinerja manajemen perusahaannya yang baik, yang berdampak menguntungkan bagi reputasi manajerialnya sebagai pengelola perusahaan dan berdampak menguntungkan bagi tingkat kemakmurannya sebagai pemilik. Meski demikian, berpengaruhnya kepemilikan manajerial terhadap tingkat hutang ini tidak selalu membuat perusahaan mengutamakan hutang sebagai sumber dana eksternal. Hal ini terlihat dari bagaimana perusahaan sampel senantiasa berada dalam posisi Jakarta Islamic Index selama periode penelitian 2004-2014. Pemilik manajerial tersebut tetap mengantisipasi ketentuan komposisi hutang sesuai kriteria atau prinsip syariah yang tertuang dalam Dewan Syariah Nasional dan Peraturan Bapepam-LK No.IX.A.13 mengenai penerbitan efek syariah. Dalam hal ini, kepemilkan manajerial tetap mampu mengontrol komposisi tingkat hutangnya. 
Berdasarkan hasil pengujian regresi dalam tabel 7, kepemilikan institusional memiliki pengaruh terhadap tingkat hutang pada perusahaan publik yang bertahan dalam posisi Jakarta Islamic Index selama kurun waktu penelitian 2004-2014. Hal ini terbukti dengan adanya nilai koefisien regresi variabel kepemilikan institusional sebesar -1,432 dengan signifikasi sebesar 0,038 yang berada di bawah tingkat signifikasi $(\alpha) 5 \%$. Hasil penelitian ini berbeda dengan hasil penelitian Moeinaddin dan Karimianrad (2012) serta Shoroki, Addin, dan Jamalabadi (2013) namun sejalan dengan hasil penelitian Abdoli, Lashkary, dan Dehghani (2012), Hussainey dan Aljifri (2012), Mousavi, Jari, dan Aliahmadi (2012), serta Kurniawan dan Rahardjo (2014) mengemukakan adanya pengaruh antara kepemilikan institusional terhadap tingkat hutang.

Dalam sudut pandang agensi, kepemilikan institusional memiliki insentif untuk memonitor perilaku oprtunistik manajemen. Dalam hal ini, pemilik institusi cenderung bersikap sebagai penghindar risiko sehingga menginginkan suatu tingkat hutang yang tidak besar. Penekanan besarnya komposisi tingkat hutang ini juga mendorong perusahaan untuk tidak menyimpang dari ambang batas tingkat hutang dalam prinsip efek syariah. Pemilik institusi tersebut turut mengantisipasi ketentuan komposisi hutang, yang dengan kata lain pula turut memonitor tingkat hutang yang sesuai kriteria atau prinsip syariah yang tertuang dalam Dewan Syariah Nasional dan Peraturan Bapepam-LK No.IX.A.13 mengenai penerbitan efek syariah. Dalam hal ini, kepemilkan institusional memiliki usaha pengawasan yang efektif untuk meyakinkan pihak manajemen perusahaan agar senantiasa mengontrol dengan baik komposisi tingkat hutangnya.

Berdasarkan hasil pengujian regresi dalam tabel 7, komisaris independen memiliki pengaruh terhadap tingkat hutang pada perusahaan publik yang bertahan dalam posisi Jakarta Islamic Index selama kurun waktu penelitian 2004-2014. Hal ini terbukti dengan adanya nilai koefisien regresi variabel komisaris independen sebesar -2,673 dengan signifikasi sebesar 0,000 yang berada di bawah tingkat signifikasi ( $\alpha$ ) 5\%. Hasil penelitian ini berbeda dengan hasil penelitian Moeinaddin dan Karimianrad (2012) serta Shoroki, Addin, dan Jamalabadi (2013) namun sejalan dengan hasil 
penelitian Abdoli, Lashkary, dan Dehghani (2012), Bobkin dan Arko (2012), serta Kajananthan (2012) menyimpulkan pengaruh antara komisaris independen terhadap tingkat hutang.

Dalam sudut pandang agensi, komisaris independen diyakini mampu menjembatani kepentingan pemilik dan pengelola perusahaan. Dalam hal ini, komisaris independen cenderung mengawasi dan mengarahkan perusahaan untuk menekan tingkat hutang sehingga meminimalisir risiko yang mampu membahayakan finansial perusahaan. Penekanan terhadap besarnya komposisi tingkat hutang ini juga mendorong perusahaan untuk tidak menyimpang dari ambang batas tingkat hutang dalam prinsip efek syariah. Komisaris independen yang turut mengantisipasi ketentuan komposisi hutang tersebut juga berkontribusi di dalam memonitor dan mengarahkan tingkat hutang yang sesuai kriteria atau prinsip syariah yang tertuang dalam Dewan Syariah Nasional dan Peraturan Bapepam-LK No.IX.A.13 mengenai penerbitan efek syariah. Dalam hal ini, komisaris independen memiliki usaha pengawasan dan pengarahan yang baik dan efektif untuk mengendalikan pihak manajemen perusahaan agar senantiasa mengatur dengan bijak komposisi tingkat hutangnya.

Berdasarkan hasil pengujian regresi dalam tabel 7, profitabilitas tidak memiliki pengaruh terhadap tingkat hutang pada perusahaan publik yang bertahan dalam posisi Jakarta Islamic Index selama kurun waktu penelitian 2004-2014. Hal ini terbukti dengan adanya nilai koefisien regresi variabel profitabilitas sebesar 0,272 dengan signifikasi sebesar 0,554 yang berada di atas tingkat signifikasi $(\alpha)$ $5 \%$. Hasil penelitian ini berbeda dengan hasil penelitian Margaretha dan Ramadhan (2012), dan Widyarini dan Muid (2014) namun sejalan dengan hasil penelitian Sultera, Suhadak, dan Darminto (2014) dimana profitabilitas tidak mampu memengaruhi tingkat hutang.

Dalam sudut pandang teori pecking order, perusahaan cenderung memilih pembiayaan internal terlebih dahulu. Namun hasil penelitian ini membuktikan hal yang berbeda, dimana dalam kondisi profitabilitas rendah maupun tinggi, perusahaan tetap mempertimbangkan sumber pembiayaan eksternal, terutama 
hutang, namun masih dalam batas koridor komposisi hutang yang sesuai dengan kriteria atau prinsip syariah.

Berdasarkan hasil pengujian regresi dalam tabel 7 , likuiditas memiliki pengaruh terhadap tingkat hutang pada perusahaan publik yang bertahan dalam posisi Jakarta Islamic Index selama kurun waktu penelitian 2004-2014. Hal ini terbukti dengan adanya nilai koefisien regresi variabel likuiditas sebesar -0,094 dengan signifikasi sebesar 0,019 yang berada di bawah tingkat signifikasi $(\alpha)$ $5 \%$. Hasil penelitian ini sejalan dengan hasil penelitian Margaretha dan Ramadhan (2012), Sultera, Suhadak, dan Darminto (2014), dan Widyarini dan Muid (2014) menyatakan bahwa likuiditas memiliki pengaruh terhadap tingkat hutang.

Dalam sudut pandang teori pecking order, perusahaan dengan tingkat likuiditas yang tinggi cenderung menekan tingkat hutangnya. Melalui tingkat aset lancar yang memadai, perusahaan merasa mampu membiayai aktivitas operasional dan investasinya, sehingga tingkat hutang serta risiko finansial yang dihadapi perusahaan pun semakin kecil. Dalam hal ini, likuiditas yang berpotensi menekan tingkat hutang memiliki kontribusi dalam mengontrol komposisi tingkat hutang perusahaan yang sesuai dengan kriteria atau prinsip syariah.

Berdasarkan hasil pengujian regresi dalam tabel 7 , struktur aset tidak memiliki pengaruh terhadap tingkat hutang pada perusahaan publik yang bertahan dalam posisi Jakarta Islamic Index selama kurun waktu penelitian 2004-2014. Hal ini terbukti dengan adanya nilai koefisien regresi variabel struktur aset sebesar 0,115 dengan signifikasi sebesar 0,642 yang berada di atas tingkat signifikasi $(\alpha)$ 5\%. Hasil penelitian ini tidak konsisten dengan hasil penelitian Sultera, Suhadak, dan Darminto (2014), serta Widyarini dan Muid (2014) yang menyatakan bahwa struktur aset memiliki pengaruh terhadap tingkat hutang.

Dalam sudut pandang teori pecking order, perusahaan akan memilih pembiayaan eksternal jika pembiayaan internal dirasa tidak memadai. Kemudian, apabila perusahaan memiliki aset tetap yang besar, maka dapat meningkatkan keyakinan perusahaan untuk mencari sumber dana berupa hutang karena lebih memiliki 
jaminan pengembalian yang pasti jika menghadapi risiko finansial ke depannya. Namun hasil penelitian ini membuktikan hal yang berbeda, dimana dalam struktur aset yang kecil maupun besar, perusahaan tetap mempertimbangkan hutang sebagai sumber pembiayaan eksternal, dengan mengupayakan batas koridor komposisi hutang yang sesuai dengan kriteria atau prinsip syariah.

Berdasarkan hasil pengujian regresi dalam tabel 7 , ukuran perusahaan tidak memiliki pengaruh terhadap tingkat hutang pada perusahaan publik yang bertahan dalam posisi Jakarta Islamic Index selama kurun waktu penelitian 2004-2014. Hal ini terbukti dengan adanya nilai koefisien regresi variabel ukuran perusahaan sebesar 0,069 dengan signifikasi sebesar 0,240 yang berada di atas tingkat signifikasi ( $\alpha$ ) 5\%. Hasil penelitian ini berbeda dengan hasil penelitian Margaretha dan Ramadhan (2012) yang menyatakan bahwa ukuran perusahaan berpengaruh terhadap tingkat hutang, namun sejalan dengan hasil penelitian Sultera, Suhadak, dan Darminto (2014), serta Widyarini dan Muid (2014) yang menyatakan bahwa ukuran perusahaan tidak memiliki pengaruh terhadap tingkat hutang.

Dalam sudut pandang teori pecking order, perusahaan akan memilih pembiayaan eksternal jika pembiayaan internal dirasa tidak memadai. Perusahaan dengan ukuran besar mencerminkan kebutuhan pendanaan yang besar pula untuk membiayai aktivitasnya. Perusahaan dengan ukuran besar juga cenderung menghasilkan arus kas yang stabil dari diversifikasi usahanya yang luas. Hal in mendorong perusahaan untuk memperoleh hutang sebagai sumber dana eksternalnya. Namun hasil penelitian ini membuktikan hal yang berbeda, dimana dalam ukuran perusahaan yang kecil maupun besar, perusahaan tetap mempertimbangkan sumber pembiayaan eksternal, terutama hutang, namun masih dalam batas koridor komposisi hutang yang sesuai dengan kriteria atau prinsip syariah.

\section{Kesimpulan}

Penelitian ini telah mengidentifikasi beberapa faktor yang mampu memengaruhi dan mengontrol tingkat hutang perusahaan publik yang bertahan dalam posisi Jakarta Islamic Index selama 2004-2014, 
supaya tetap sesuai kriteria atau prinsip syariah yang tertuang dalam Dewan Syariah Nasional dan Peraturan Bapepam-LK No.IX.A.13 mengenai penerbitan efek syariah, sekaligus tetap menjadi saham syariah unggulan. Kesimpulan yang merupakan jawaban permasalahan ini yakni: 1) Kepemilikan manajerial berpengaruh terhadap tingkat hutang. 2) Kepemilikan institusional berpengaruh terhadap tingkat hutang. 3) Komisaris independen berpengaruh terhadap tingkat hutang. 4) Profitabilitas tidak berpengaruh terhadap tingkat hutang. 5) Likuiditas berpengaruh terhadap tingkat hutang. 6) Struktur aset tidak berpengaruh terhadap tingkat hutang. 7) Ukuran perusahaan tidak berpengaruh terhadap tingkat hutang. Dengan demikian, kepemilikan manajerial, kepemilikan institusional, komisaris independen, dan likuiditas menjadi faktor penting dalam pengendali tingkat hutang, dimana komposisi hutang berbanding ekuitas ini tidak diperkenankan melebihi $82 \%$, atau dengan kata lain proporsi tingkat hutang maksimal adalah 45\%:55\% (BapepamLK No.IX.A.13). 


\section{Daftar Pustaka}

Abdoli, Mohamadreza, Mohammad Lashkary, dan Mohammadreza Dehghani. 2012. Corporate Governance and Its Effect on the Corporate Financial Leverage. Journal of Basic and Applied Scientific Research, Vol. 2, No. 9, ISSN 2090-4304

Bokpin, Godfred A. dan Anastacia C. Arko. 2012. Ownership Structure, Corporate Governance and Capital Structure Decisions of Firms: Empirical Evidence from Ghana. Studies in Economics and Finance, Vol. 26, No. 4: 246-256, DOI 10.1108/10867370910995708

Fama, Eugene, dan Michael Jensen. 1983a. Separation of Ownership and Control. Journal of Law and Economics, hlmn: 301-325

Ghozali, Imam. 2013. Aplikasi Analisis Multivariate dengan Program IBM SPSS 21. Semarang: Badan Penerbitan Universitas Diponegoro

Hussainey, Khaled dan Khaled Aljifri. 2012. Corporate Governance Mechanisms and Capital Structure in UAE. Journal of Applied Accounting Research, Vol. 13, No. 2: 145-160, DOI 10.1108/09675421211254849

Jensen, Michael C. 1986. Agency Cost of Free Cash Flow, Corporate Finance and Take Overs. American Economics Review, Vol. 76, No 2: 323-329.

Jensen, M.C. dan Meckling, W.H. 1976. Theory of the Firm: Manajerial Behaviour, Agency Cost and Ownership Structure. Journal of Financial Economics, Vol. 3, No. 40: 305-60.

Kajananthan, Rajendran. 2012. Effect of Corporate Governance on Capital Structure: Case of The Srilanka Listed Manufacturing Company. International Refereed Research Journal - Journal of Arts, Science \& Commerce, Vol. III, Issue-4(1), E-ISSN 2229-4686, ISSN 2231-4172 
Kurniawan, Vito Janitra, dan Shiddiq Nur Rahardjo. 2014. Pengaruh Antara Tata Kelola Perusahaan (Corporate Governance) dengan Struktur Modal Perusahaan. Diponegoro Journal of Accounting, Vol. 3, No. 3, Hlmn: 1-9, ISSN (Online): 23373806

Margaretha, Farah dan Aditya Rizky Ramadhan. 2010. Faktor-Faktor yang Mempengaruhi Struktur Modal Pada Industri Manufaktur di Bursa Efek Indonesia. Jurnal Bisnis dan Akuntansi, Vol. 2 No. 2, Hlmn : 119-130

Moeinaddin, Mahmoud dan Mohsen Karimianrad. 2012. The Relationship between Corporate Governance and Finance Patterns of the Listed Companies. Interdisciplinary Journal of Contemporary Research in Business, Vol. 4, No. 7

Mousavi, Zahra, Azam Jari, dan Saied Aliahmadi. 2012. The Evaluation of Corporate Governance Monitoring Mechanisms on Capital Structure in Tehran Stock Exchange. International Journal of Business and Social Science, Vol. 3, No. 1

Myers, Stewart dan Nicholas S. Majluf. 1984. Corporate Financing and Investment Decision When Firms Have Information That Investors Do Not Have. Journal of Financial Economics, Vol. 13, No. 2, Hlmn: 187-221

Shoroki, Mohsen Rezaee, Mahmood Moein Addin, dan Hamid Reza Ranjbar Jamalabadi. 2013. Corporate Governance Mechanisms and Debt Structure Intensity. Interdisciplinary Journal of Contemporary Research in Business, Vol. 4, No. 9

Sultera, Fatimah Karunia, dan Darminto Suhadak. 2014. Pengaruh Aspek Fundamental dan Risiko Bisnis Terhadap Financial Leverage (Studi pada Perusahaan Manufaktur Sektor Aneka Industridi BEI Periode Tahun 2007 - 2011). Jurnal profit, Vol. 6 No.2

Widyarini, Rahmadian dan Dul Muid. 2014. Analisis Faktor-Faktor 
yang Mempengaruhi Leverage Pada Perusahaan Tambang yang Terdaftar Di Bursa Efek Indonesia pada Periode Tahun 2009-2012. Diponegoro Journal of Accounting, Vol. 3, No. 3, ISSN (Online): 2337-3806

www.idx.co.id 